\title{
関東山地東部の三波川変成岩類中の緑閃石
}

\section{Actinolite in the eastern part of the Kanto Mountains}

\author{
関陽太郎 (Yôtarô Seki)*
}

\begin{abstract}
Glaucophanitic regional metamorphic terrain in the eastern part of the Kanto Mountains can be divided into the following two parts; pale coloured actinolite zone and greenish blue actinolite zone. Though the greenish blue actinolite is only found in the highest grade part of the terrain; "spotted schist zone", pale coloured actinolites are chiefly distributed in the non-spotted schists, phyllites or weakly metamorphosed Paleozoic formation. These two kinds of actinolite can be easily discriminated to each other by their optical properties (Figure 1).

Chemical, optical and X-ray data of these two actinolites are also given in this paper.
\end{abstract}

\section{1. 緒言}

1938 年，堀越が発表した四国别子地方の三波川筑成岩類の中にある角閃石故の研究 は，当時の三波川変成带研究に々つて新しい万法であり，又，注目すべき結喿であつた。 そして，三波川変成岩の造岩鉣物の研究としてここの垤越の研究に十分肩を並べうるもの は，それ以後 1957 年頃まで報告されたことがない。筆者は，関東山地東部の三波川帘成 岩類の岩石学的研究を進める過程で、これらの変成岩類の中の mafic 火山嘪出岩および 貫入岩を源岩とする緑色变成岩に，きわめて普屚的にみられる緑閃石 (actinolite) の光 学的・化学的性質と産状とに注目した。その結果は，上にあげた堀越の四国の三波川結晶 片岩で出した結果および彼がその論文中で関東山地の三波川変成岩中の緑畞石に就いて 述べたことに，ま浪近いものであつた。関東山地の三波川変成岩然の中には，mafic な

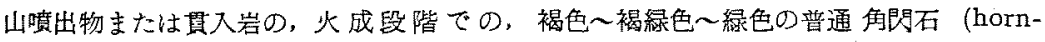
blende) が残晶としてしばしぼ見出されるが，変成作用にともなつて出来だ触石とし ては普通角閃石と考えられるものはないもつとも屈折率の高いものでも, 後に述べる如 く、緑畞石と称さるべきものである。斜力角閃石はまだ見出されたことがない。

この研究では，東京大学都城秋穂および柴藤文子氏から，有益な助言を得た。X-線粉 末データをうるにあたつては，紫藤文子氏を通して，東京大学理学部地質学教空皆石学研 究公より多くの援助を得た。以上の各氏にふ亦く感謝する。

\section{2. 緑閃石の分布と鉱物組合せ}

関東山地に於ける三波川変成岩類の中での緑閃石の分布範囲の層序的な上限は, 前に述

* 埼玉大学文理学部地学教空

1）堀越義一：地質，45，290～301，1938. 
ベたリーベカイトまたはマグネシオリーベカイト成分に富むアルカリ角閃石のそれいに

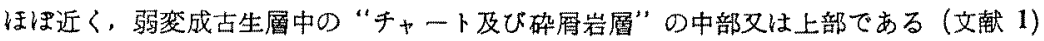
の第 1 图参照）緑閃石はそれ以下，この地域の最下部層である点效片岩層にまでの間の， mafic な火山噴出岩および貸入岩源の変成岩の中に広く分布する。このような緑閃石を 鏡下で見る時, これらの緑䀧石が層序的な上下によつて，汪二種にわけられうることに 気付く。それは，点皎片岩層内の緑色片岩に限られて見出される比較的濃い青緑色の多色

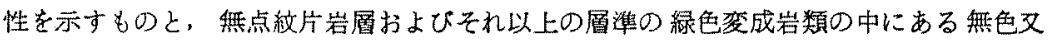
は，淡緑・淡黄緑色の多色性のものとである。両種の緑閃石の分布の境は, 決して確然た るものではないし，文，その境が点秝・無点效の片岩層の境(これも決して一つのきまつ た面で表わされうるものではないが）に常に一致するものでもない。例えば呴居町西部で は，淡緑色緑閃石が無点絃片岩層の下限より点紋片岩層の中にまで広く見出されている。 しかし，点紋片岩層中に安定にある緑色片岩の緑閃石が主として，青緑色緑閂石であり， 又，青緑色緑閃石は，点紋片岩層の中でのみ安定に見出される（弱変成古生層のなかの mafic な貫入岩で，褐色普通角門石を围んで青緑色緑閃石の出来ていることがあるけれ ぞもこれらの緑閃石は常に，無色ないし淡緑色の緑閃石によつて囲まれている)。こ れらの緑閃石のうち，青緑色緑閃石は緑泥石・チタナイト・スティルフフォレーン・白雲

第 1 図

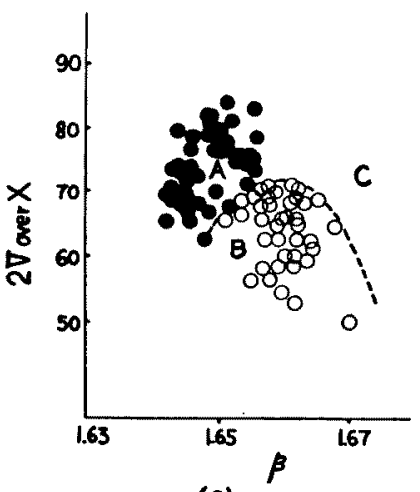

(a)

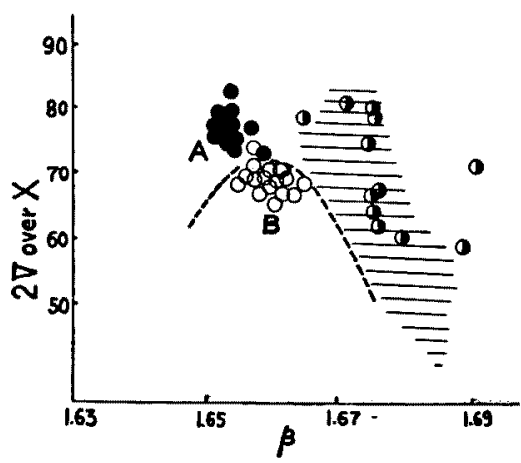

(b)

(a) 関東山地東部の変成岩中の緑閃石の光軸角と $\beta$ との関係

○：点紋結晶片岩層の緑眨石

-：無点紋片岩層抢よびそれ以上の層準の四緑石

（b）青海地方の結晶片岩中の緑閃石の光軸角之 $\beta$ との関係

○：緑泥石带の中の变成度のた加い部分の緑嗿石

- : 緑泥石带の中の変成度のUくい部分の緑閃石

○：黒雲母带の青緑色普通角閃石 (ハッチした部分は，阿武隅山地の角閃岩〜エビドート角閃岩 中の曾通角閃石のフィールドを示す)

1）関 陽太郎：岩鉱，42，128１35，1958. 
母・エビドート・石英・曹長石・稀にサクロ石と安定に共存する。無色一淡色緑卵石は， エピドート・パンベリー石・緑泥石・キタナイト・スティルプノメレーン・白雲母・石

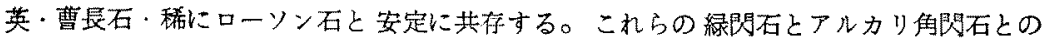
関係は，すでに報告した通りである゙リが，その中，点酰片岩層にあるアルカリ角閃石(リ 一ベカイト又はマグホシオリーベカイト成分に富む) は，常に不安定な形で青緑色緑門石 につつまれていることは注目すべき事实である。

\section{3. 光学恒数について}

上に述べなうな分布を示す緑閃石の $\beta$ と $2 \mathrm{~V}_{\mathrm{s}}$ を幾つ加測定して，それらの值を，

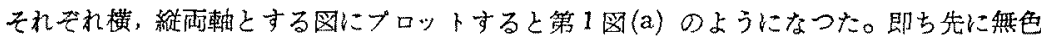
ないし淡色緑閃石と样んだものと，青緑色と呼んだものとは，光学的性質によつて相当は つきり区別されうる。之を，先にあげた堀越のデータと比較すると，堀越が四国別子地方 で green schist と呼んたもも中の緑閃石が，関東山地での青緑色緑間石に，同しく堀 越が green phyllite と㭔んだものの中の緑閃石が関東山地での無色～淡色緑閃石にほ 泪当するものであるらしい。多色性もそれぞれ極めてよく一致するし，又この論文の 第1図は堀越の論文の第7㘠（堀越は $\beta$ でなく，嬖開片上に於汗る $\mathrm{N}_{2 D}(\fallingdotseq \gamma)$ をはかつ たが)とよく一致する。

このような区別は，上に述べたように四国の三波川変成岩類にも通用するらしいが，更 に他の広域変成域の変成度への分带にも用いられうるらしい。例えほ，筆者が看へた限り

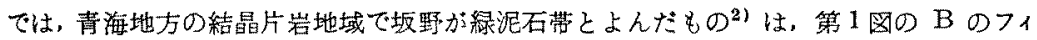
ールトに入る光学的性質の緑閃石をもつ緑色片岩がある部分と，A のフィールトに入る 緑閣石で特街つけられる緑色片岩をもつ部分とに二分され得る（第 1 (b) 図）。前者は， 坂野の黒雲亚に移化し，坂野によるとその中に藍聞石片岩がないが，後者には，藍閃石 片岩を介在するという。

\section{4. 化学成分}

第 1 図の A，B の2つのフィールトに落ちる光学的性筫を持つ緑聞石をそれぞれ $1 つ$ つつ, 緑色片岩加らアイソダイナミックセパレーターとクレリシ泖を用いて分離した。不 純物としてこく僅かのチタナイトが入つて居るのを除いては，行離結果はほ涩満足すべき ものであつた。それらのサンフルの化学組成は第 1 表に示されて居る通りである（光学的 性質も付記した)。

第 1 表から青緑色緑閃石 (II) は無色緑閃石（I) に較へてて $\mathrm{Fe}^{\prime \prime} / \mathrm{Mg}$ 比が大きく，且 つ Al の多いことがわかる。このことは，それらの光学的性䁈加らも大体推定され得るこ とであり，及，再結晶の程度その他の点3) より考えて，青緑色緑閃石で特街つけられる

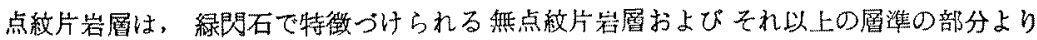
も、おそらく変成度が高い(少くともより高温で变成された)であるうと思われる事とよ く一致する。

1) 関 陽太郎：前出, 1958.

2) Banno, S. : Jap. Jour. Geol. Geogr. (in press)

3) 関 陽太郎·加藤干草：岩鉱，43，57 63, 1959.

4). Miyashiro, A. and Seki, Y. : Am. Jour. Sci., 256, 423 430, 1958. 
第 1 表 関東山地東部の緑莭石の化学成分と光学的性實

\begin{tabular}{|c|c|c|}
\hline & I & II \\
\hline $\mathrm{SiO}_{2}$ & 56.06 & 50.55 \\
\hline $\mathrm{TiO}_{2}$ & n.d. & n.d. \\
\hline $\mathrm{Al}_{2} \mathrm{O}_{3}$ & 2.14 & 6.51 \\
\hline $\mathrm{Fe}_{2} \mathrm{O}_{3}$ & 2.22 & 5.40 \\
\hline $\mathrm{FeO}$ & 8.97 & 11.58 \\
\hline $\mathrm{MnO}$ & 0.23 & 0.32 \\
\hline $\mathrm{MgO}$ & 16.11 & 10.72 \\
\hline $\mathrm{CaO}$ & 10.28 & 9.77 \\
\hline $\mathrm{Na}_{2} \mathrm{O}$ & 1.36 & 1.46 \\
\hline $\mathrm{K}_{2} \mathrm{O}$ & 0.00 & 0.18 \\
\hline $\mathrm{H}_{2} \mathrm{O}+$ & 2.42 & 2.89 \\
\hline $\mathrm{H}_{2} \mathrm{O}-$ & 0.17 & 0.31 \\
\hline \multirow[t]{2}{*}{ Total } & 99.96 & 99.69 \\
\hline & I & II \\
\hline$\alpha$ & 1.626 & 1.648 \\
\hline$\beta$ & $1.634=0.002$ & $1.661 \pm 0.002$ \\
\hline$\gamma$ & $1.640 !$ & 1.669 \\
\hline$\gamma-\alpha$ & 0.014 & 0.021 \\
\hline$(-) 2 \mathrm{~V}$ & $\begin{array}{l}76^{\circ}-80^{\circ} \\
\quad \text { (average } 78^{\circ} \text { ) }\end{array}$ & $\begin{array}{l}61^{\circ}-68^{\circ} \\
\quad\left(\text { average } 65^{\circ}\right)\end{array}$ \\
\hline$c \wedge Z$ & $24^{\circ}$ & $30^{\circ}$ \\
\hline $\mathrm{x}$ & colourless & $\begin{array}{l}\text { pale yellowish } \\
\text { brown }\end{array}$ \\
\hline $\mathrm{Y}$ & pale yellow & $\begin{array}{l}\text { pale bluish } \\
\text { green }\end{array}$ \\
\hline$Z$ & $\begin{array}{l}\text { pale brownish } \\
\text { yellow }\end{array}$ & $\begin{array}{l}\text { pale greenish } \\
\text { yellow }\end{array}$ \\
\hline orientati & on $\mathrm{b}=\mathrm{Y}$ & $\mathrm{b}=\mathrm{Y}$ \\
\hline
\end{tabular}

\begin{tabular}{|c|c|c|c|c|}
\hline & \multicolumn{2}{|c|}{ I } & \multicolumn{2}{|c|}{ II } \\
\hline O & 23 & & 23 & \\
\hline $\mathrm{Si}$ & 7.93 & 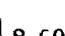 & 7.42 & 100 \\
\hline$\Delta$ & 0.07 & & 0.58 & \\
\hline & 0.28 & & 0.54 & \\
\hline $\mathrm{Fe}^{\prime \prime \prime}$ & 0.24 & & 0.60 & \\
\hline $\mathrm{Fe}^{\prime \prime}$ & 1.06 & 5.01 & 1.42 & 4.94 \\
\hline $\mathrm{Mn}$ & 0.03 & & 0.04 & \\
\hline $\mathrm{Mg}$ & 3.40 & & 2.34 & \\
\hline $\mathrm{Ca}$ & 1.55 & & 1.54 & \\
\hline $\mathrm{Na}$ & 0.37 & 1.92 & 0.41 & 1.98 \\
\hline $\mathrm{K}$ & ....... & & 0.03 & \\
\hline $\mathrm{H}_{2} \mathrm{O}$ & 1.14 & & $1 . \angle 5$ & \\
\hline
\end{tabular}

I：緑閃石・エピドート・緑泥石 . チタナイト・石英・曹長石片岩 中の淡色緑閃石（埼玉罧東秩父 村白石)，原子比は $\mathrm{H}_{2} \mathrm{O}$ を除 いた時に $0=23$ として計算さ れた。(分析者, 関・加藤干草)。

II : 緑聞石・エビドート・緑泥石.

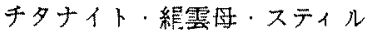
プノメレーン・石英・曹長石片 岩中の緑青石緑閃岩（埼玉目 東秩父村大内沢)，原子比は， $\mathrm{H}_{2} \mathrm{O}$ を除いた時に $0=23$ と して計算された。（分析者，関 加藤千草)。

\section{X-線 解析值}

Philips ガイガー計数管 X-線 diffractometer (Cu-Ka) を用いて得られたデー夕を もとにして、これらの緑朋石の格子恒数を算出し指数化を試みた結果は，第 2 表に示され て居る。これら 2 種の緑即石には，前に述べたような，化学組成上の差があるにもかっわ らず，格子恒数などに関しては，両者の間に全くといつてよい程差がない。

単䣄角閒石のX-線データによる指数化は，1954 年に，人工透角閏石について Comefero と Kohn とによつて発表されておりわ，第 2 表の值は，Comefero らによる

1) Comefero, J.E. and Kohn, J.A. : Am.Min., 39, 537 548, 1954. 
第 2 表 関東山地東部の緑閃石の X-線データと格子恒数 ( $\mathrm{CuK} \alpha)$ I, II は，第 1 表の I，IIにそれぞれ対怹する

\begin{tabular}{|c|c|c|c|c|}
\hline \multirow{2}{*}{ Indices } & \multicolumn{2}{|c|}{ I } & \multicolumn{2}{|c|}{ II } \\
\hline & $2 \theta$ & Intensity & $2 \theta$ & Intensity \\
\hline $\begin{array}{l}020 \\
110 \\
130 \\
111 \\
200 \\
040 \\
220 \\
131\end{array}$ & $\begin{array}{c}9.7 \\
10.4 \\
17.38 \\
18.07 \\
\ldots \ldots . \\
19.57 \\
21.02 \\
22.83\end{array}$ & $\begin{array}{r}15 \\
100 \\
14 \\
19 \\
\ldots \\
23 \\
9 \\
15\end{array}$ & $\begin{array}{c}9.7 \\
10.4 \\
17.39 \\
17.99 \\
18.69 \\
19.61 \\
21.02 \\
22.80\end{array}$ & $\begin{array}{r}9 \\
100 \\
9 \\
15 \\
8 \\
16 \\
9 \\
10\end{array}$ \\
\hline$\left\{\begin{array}{l}131 \\
041\end{array}\right.$ & 26.24 & 40 & 26.24 & 30 \\
\hline $\begin{array}{l}240 \\
310\end{array}$ & $\begin{array}{l}27.12 \\
28.69\end{array}$ & $\begin{array}{l}40 \\
80\end{array}$ & $\begin{array}{l}27.16 \\
28.72\end{array}$ & $\begin{array}{l}46 \\
80\end{array}$ \\
\hline $\left.\begin{array}{l}221 \\
151\end{array}\right\}$ & 30.30 & 36 & 30.32 & 20 \\
\hline $\begin{array}{l}330 \\
331 \\
151 \\
061 \\
20 \overline{2} \\
350 \\
351 \\
31 \overline{2} \\
261 \\
202 \\
351 \\
461\end{array}$ & $\begin{array}{l}31.83 \\
32.70 \\
33.01 \\
34.52 \\
35.32 \\
37.63 \\
38.40 \\
39.56 \\
41.63 \\
44.26 \\
44.80 \\
55.53\end{array}$ & $\begin{array}{r}16 \\
22 \\
73 \\
19 \\
23 \\
15 \\
29 \\
10 \\
22 \\
9 \\
13 \\
17\end{array}$ & $\begin{array}{l}31.86 \\
32.69 \\
33.00 \\
34.48 \\
35.29 \\
37.65 \\
38.41 \\
39.56 \\
41.62 \\
44.16 \\
44.85 \\
55.53\end{array}$ & $\begin{array}{r}17 \\
24 \\
70 \\
29 \\
23 \\
10 \\
40 \\
5 \\
10 \\
8 \\
9 \\
14\end{array}$ \\
\hline $\begin{array}{l}\mathrm{a} \\
\mathrm{b} \\
\mathrm{c} \\
\beta\end{array}$ & \multicolumn{2}{|c|}{$\begin{array}{r}9.86 \AA \\
18.13 \AA \\
5.28 \AA \\
75^{\circ} 20^{\prime}\end{array}$} & \multicolumn{2}{|c|}{$\begin{array}{r}9.86 \AA \\
18.10 \AA \\
5.31 \AA \\
75^{\circ} 20^{\prime}\end{array}$} \\
\hline
\end{tabular}

ものによく一㮹する。

\section{6. 討 論}

この論文ちよび筆者による関東山地の三波川変成岩類に関する今迄の一連の論文 ${ }^{1 / 2) 314)}$ から，関東山地では，不変成ないし弱変成古生層より点紋結晶片岩層までの間に，全体と して，一連の增進変成作用があつたと容易に結諭され得る。そして, 関東山地に於ける增 進変成作用の最高度の部分を示すと思われる所に第 1 表 II にあげた青緑色緑閃石が出来 たのである。

1) 関 陽太郎：岩鉱, 41, 155 163, 1957.

2) " : 岩鉱, 41, 227 235, 1957.

3) " : 前出, 1958 .

4) 関 陽太郎·加藤干草：前出，1958. 
堀越が园国别子地方の三波川变成岩中の角閃石の研究の結果を報告した時に，次のよう な注目すへさことを述へているのをこっで想起しなくてはならない。“関東山地の結晶片 岩区域中には，別子附近で筆者が含黑雲母るいは含ザク口石片岩带とせる部に相当する 岩石は見当らない。岩石の見掛けも，角閃石の性筫も，関東山地の大部分の結昆片岩は，

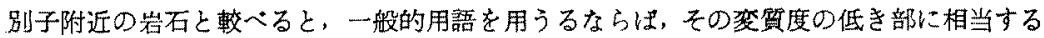
々考えられる”。堀越の推論をそのま〉考えると，関東山地の最高変成度を示すと思われ る点皎岩層より更に变成度の高い部分がもしあつたとすれば，それは，別子附近の頁岩・ 砂岩源の結晶片岩の中に黒雲母の出来ていることで特徴づけられる䏱越の含黒雲母片岩 带又は最近の坂野の研究による累雲母带1てでくてはならない。及，坂野によつて研究さ れた青海地域の黒雲母带2゙に対尤するものであるかも知れない。前にこの論文の中で述 ベたように，焻閃石の光学的性質からすると関東山地の点紋片岩带とそれ以上の層準の部 分とは，青海に於ける緑泥石带の変成度のたかい部分と，それより低变成度の部分とに， それそれ対応する。及，筆者の調へた範囲では，青海で坂野が黒雲母带とした，頁岩・矽 岩源の結晶片岩に黒雲母が普遍的に見られる部分に介在する緑色変成岩（エピドート角閃 岩と言うべきものでるう）の中の角閃石は，関東山地の緑色片岩の中にはまだ見出され たことがない，いわゆる普通角㮣石と言うへきものであり，第 1 図 C 部分に入る光学的

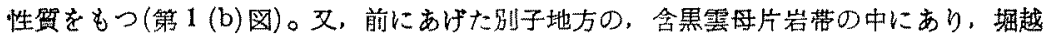
が “spotted hornblende schist" とした岩石のなかの曾通角閃石の光学的性質は，上 に述へた青海の黒雲母带の中の緑色岩のなかの普通角閃石の光学的性質と類似する。

このような，何門石族の吟味から，関東山地，青海，別子の三地域の同しように笽閃石 賀の広域変成作用の間に第 3 表のような変成度の対比が可能ではないかと思われる。

第3表 関東山地東部，青海地方，および別子地方の，变成度の概略の対比

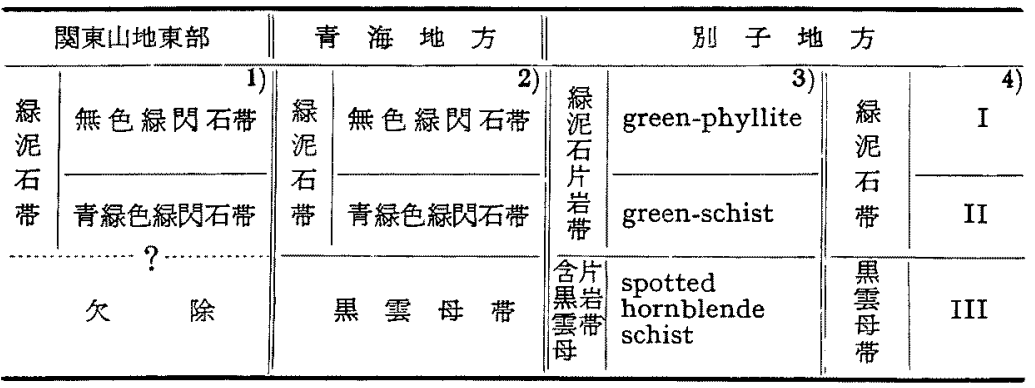

1) 本論文 2) S. Banno, 前出, 1958 3) 堀越義一, 前出, 1938

4) Miyashiro, A. \& Banno, S. 前出, 1958

勿論，筆者は，堀越がかつて述べたように，“角間石のみからかっる結諭を下すことは， むしろ乱暴であるが，“結晶片岩中に広く分布する角閃石が重要な意義を有する事は確か である”とも考えるので，あえてこ〉に，筆者の考えを提した次第である。

1) Miyashiro, A. and Banno, S. : Am. Jour. Sci., 前出, 1958.

2) Banno, S. : Jap. Jour. Geol. Geogr., 前出. 